\title{
eWOM credibility on social networking sites: A framework
}

\section{Gillian Moran \& Laurent Muzellec}

To cite this article: Gillian Moran \& Laurent Muzellec (2017) eWOM credibility on social networking sites: A framework, Journal of Marketing Communications, 23:2, 149-161, DOI: 10.1080/13527266.2014.969756

To link to this article: https://doi.org/10.1080/13527266.2014.969756

\section{4.}

6 Submit your article to this journal

III Article views: 4042

View Crossmark data \lceil

Citing articles: 21 View citing articles 


\title{
eWOM credibility on social networking sites: A framework
}

\author{
Gillian Moran* and Laurent Muzellec \\ University College Dublin, Carysfort Avenue, Blackrock, Dublin, Ireland \\ (Received 26 February 2014; final version received 16 September 2014)
}

\begin{abstract}
Social networking sites (SNS) offer brands the ability to spread positive electronic Word of Mouth (eWOM) for the purposes of building awareness and acquiring new customers. However, the credibility of eWOM is threatened of late as marketers increasingly try to manipulate eWOM practices on SNS. A greater understanding of eWOM credibility is necessary to better enable marketers to leverage true consumer engagement by generating credible peer-to-peer communications. Yet, to date, there is no one framework synthesising which factors constitute eWOM credibility in the online environment. This paper revisits the word of mouth credibility literature and proposes a new credibility framework - the 4Cs of eWOM Credibility: Community, Competence, Content, and Consensus.
\end{abstract}

Keywords: word of mouth; social media marketing; eWOM; word of mouth credibility; word of mouth marketing

\section{Introduction}

Word of mouth (WOM) or consumer-to-consumer (C2C) conversations aid the diffusion of innovations and brand-related information among receptive audiences. Experienced consumers engage in WOM exchanges to share their experiences with and provide recommendations for novice users. As such it has been considered for many years as a powerful marketing communication vector in the offline world (Dichter 1966).

The emergence of SNS and microblogs has greatly increased the ability of consumers to come together in groups of friends or strangers to discuss brands, share updates, offer advice, and relive experiences through what is now referred to as electronic WOM (eWOM). Digital consumers proffering advice on brands are no longer akin to 'market mavens' with an abundance of marketplace knowledge (Feick and Price 1987) but anybody with access to social media websites. Consequently, the credibility of eWOM is potentially affected as unknown customers may share unverified endorsements driven by ambiguous motives (Cheung et al. 2009; Palmer and Huo 2013).

Understanding the factors affecting eWOM credibility is essential for brands that are attempting to engage with their audience via SNS. Today, brands are progressively undertaking controlled-eWOM campaigns, which often reward customers for spreading brand-generated messages (Abendroth and Heyman 2013). These rewarded eWOM campaigns are particularly prevalent on SNS such as Facebook.

However, the success of these campaigns depends on their overall credibility (Ryu and Feick 2007; Schmitt, Skiera, and Van den Bulte 2011). Although a number of academic papers have investigated WOM credibility in the offline world (e.g. Gatignon and Robertson 1986; Leonard-Barton 1985; Brown and Reingen 1987; Duhan et al. 1997); to

*Corresponding author. Email: gillian.moran@ucdconnect.ie 
date there is no framework that synthesises and contextualises this research in the digital era.

This paper aims to address this gap in the literature by reviewing the literature on brand-initiated eWOM and identifying the factors affecting credibility.

It proposes a new framework, the 4Cs of eWOM Credibility, which outlines each of the four components for its relevance to eWOM engagement on SNS. The framework identifies how consumers evaluate eWOM credibility which has implications for brand managers attempting to leverage users' interpersonal networks for the spread of eWOM content.

\section{Credibility of brand-initiated e-WOM}

eWOM relates to 'any positive or negative statement made by potential, actual, or former customers about a product or company, which is made available to a multitude of people and institutions over the Internet' (Hennig-Thurau et al. 2004, 39). In essence, eWOM concerns $\mathrm{C} 2 \mathrm{C}$ conversations occurring online.

Consumers communicate with their peers to endorse or condemn products or services which they have experienced, and commonly eWOM offers truthful, balanced assessments of brands from the perspectives of their users (Cheung et al. 2009). Consumers place their trust in the advice of peers as fellow customers are not expected to have any reason to misguide them (Fong and Burton 2006). Online consumer forums, discussion boards, review and ratings sites, and SNS among other platforms bring consumers together to discuss consumption experiences where information is shared by knowledgeable users. Fellow consumers are further perceived credible as they can evaluate a potential buyer's consumption dilemma and suggest custom-tailored solutions (Wirtz and Chew 2002).

Consumers are increasingly turning to the Internet to search for and share product information, and these practices result in large volumes of consumer opinions being available online (Reichelt, Sievert, and Jacob 2014). Digital technologies have revolutionised the way consumers search for products and services, seek reviews from current and past consumers, and eventually decide whether or not to purchase. As a result, eWOM is now considered as an essential component of the consumer decision-making journey (Moran, Muzellec, and Nolan 2014). However, one detractor of eWOM credibility arises as the majority of eWOM supporting websites permit the identity of the sender to be concealed. While sender motivations are generally believed altruistic rather than aimed at manipulating fellow consumers (Phelps et al. 2004), in order to judge the credibility of the myriad of information available the onus is placed on consumers themselves to self-assess the nature of both the message and its sender (Leonard-Barton 1985).

SNS are the latest platforms through which eWOM messages are shared among individuals or groups of consumers. However, within the SNS realm, user identities are disclosed to one another. Further, eWOM messages spread on SNS are open and transparent as the message appears on the user's own profile page as well on the newsfeeds of friends connected to that user (Chatterjee 2011). Within this online domain brands are increasingly trying to leverage their 'fan' and 'follower' connections in order to attract new customers (LaPointe 2012). One way in which this leverage manifests itself is in terms of brand-initiated or 'fertilised' eWOM (Trusov, Bucklin, and Pauwels 2009). On SNS, this activity consists of brands incentivising their 'fans' to spread firm-created communications with their 'friend' connections. In 2012, Tesco, a British multinational grocery and general merchandise retailer ran a 'Share \& Earn scheme' where the retailer's Facebook fans earned loyalty card points for sharing products with their friends online. 
Brand-initiated eWOM is potentially visible to the entire friend network of the user who engaged in sharing the branded post. Although this poses significant advantages to building brand awareness, should incentives be used to encourage $\mathrm{C} 2 \mathrm{C}$ exchanges the incentive is also disclosed to the user's friend network, potentially detracting from the credibility of the eWOM message (Ryu and Feick 2007).

This high level of overt eWOM ownership on SNS may prevent customer-brand engagement from loyal customers who do not wish to be portrayed as chasing economic gain. Customers who actively engage with brands on SNS are predominantly the brand's heaviest and loyal users (Nelson-Field, Riebe, and Sharp 2012) whose engagement exhibits an emotional as well as cognitive and behavioural attachment to the brand (Hollebeek 2011). They disperse branded information among their interpersonal networks to champion their brand along with building their own social statuses as experts within the consumption category. Incentivised, brand-initiated eWOM campaigns are unlikely congruent with fans' idealised self-identities (Wallace, Buil, and de Chernatony 2012), and potentially threaten their disengagement from the brand's SNS-based activities. As such, a deeper comprehension of how receivers of eWOM in the digital domain attribute credibility to the brand-related messages they receive is imperative.

\section{Literature review approach}

The literature consulted included highly cited articles in top-tier journals which were concerned with identifying both antecedents and models of WOM credibility. A review of the literature reveals that these various credibility considerations can be organised into two broad categories. The first category includes emitter and audience factors (Hovland and Weiss 1951; Chu and Kim 2011), tie strength relationships (Granovetter 1973; Brown and Reingen 1987), receiver processing motivation and ability (Petty, Cacioppo, and Schumann 1983), and involvement levels (Chaiken 1980; Park, Lee, and Han 2007), whereas the second category includes message characteristics such as valence, sidedness, and consistency (Liu 2006; Cheung et al. 2009). However, no WOM credibility model to date includes all of these aspects. This paper aims to synthesise the various eWOM credibility stimuli into one framework. The framework is guided by the overarching domains of source and message credibility within which the more granular elements of each will be addressed in the following section.

\section{Findings: the $4 \mathrm{Cs}$ of credibility}

In an attempt to organise the literature reviewed, the eWOM source and the eWOM message emerged as the two most encompassing variables impacting the credibility of eWOM. It is proposed here that source credibility is determined by the relationship between sender and receiver (community) coupled with their respective experience levels (competence), whereas message credibility is evidenced through the substance of the communication (content) and how it resonates with the receiver (consensus). These components constitute the 4Cs of Credibility and the subsequent framework is presented in Figure 1.

\section{Community}

Community relates to the relationship between the sender and the receiver of eWOM. Previous studies have considered this relationship from one of two angles: the tie strength 


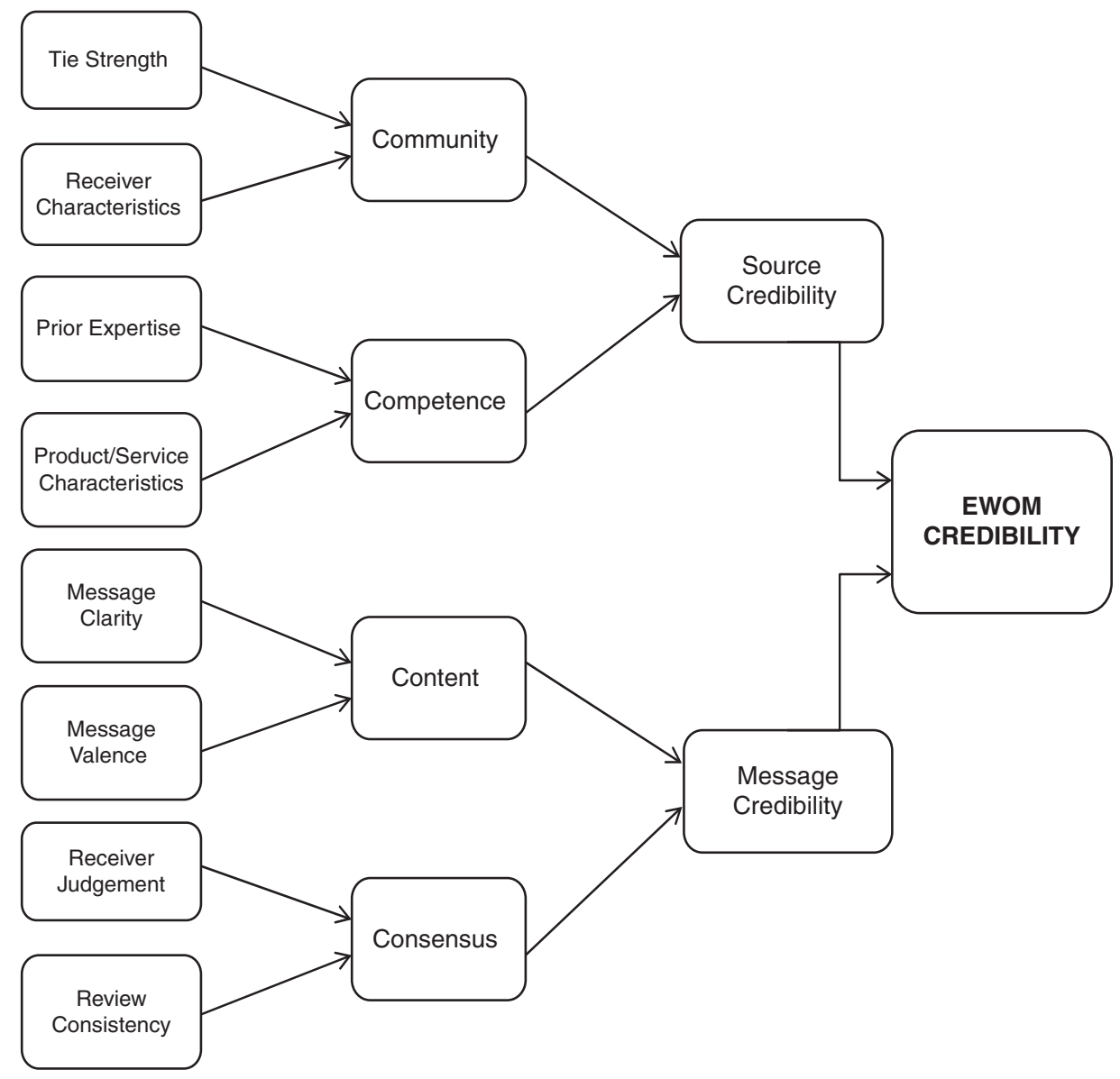

Figure 1. The 4Cs of credibility framework.

relationship (e.g. Granovetter 1973; Brown and Reingen 1987; Chu and Kim 2011) or the extent to which the receiver is susceptible to interpersonal influence (e.g. Bearden, Netemeyer, and Teel 1989; Park and Lee 2009; Lee and Ma 2012).

Traditionally, WOM communications in the offline environment occurred between people who exhibited strong tie connections such as between close friends or family members (Dichter 1966). WOM was considered truthful, honest, believable, and relevant as the message was emanating from trustworthy sources concerning their own experiences with products and brands (Wirtz and Chew 2002). Credibility was therefore presumed as an inherent factor in WOM messages from strong-tie sources (Kozinets et al. 2010).

However, with the development of the Internet enabling eWOM to be posted anonymously the personal connection linking sender and receiver was removed (Chatterjee 2011). Consumers with weak or absent prior relationships became the primary source of $\mathrm{C} 2 \mathrm{C}$ communications in the computer-mediated environment (Duhan et al. 1997).

This distinction has led to two contradictory schools of thought developing around the credibility of online WOM. Firstly, the ability to converse with experienced consumers outside of one's social circle (i.e. weak or absent ties) enhances knowledge transfer or 
'know-how trading', which adds value to the consumption experience (Gruen, Osmonbekov, and Czaplewski 2005). Further, an unknown consumer is still a fellow consumer and most likely sharing his or her experiences out of concern for others (Phelps et al. 2004). Thus, if the eWOM receiver perceives no reason to doubt the information, it will be considered credible and the recommendation followed (Cheung et al. 2009). Conversely, the opposing camp posits that eWOM is spread by unknown people with unknown motives who can conceal their true identities and post anonymously (Dellarocas 2003). This anonymity detracts from credibility. Further, positive eWOM is conceivably spread by marketers posing online as satisfied customers in a deceitful attempt to bolster brand reputations (Godes and Mayzlin 2009). In addition, as the motivations behind the spreading of eWOM are undisclosed and difficult to decipher, customers may well be remunerated by brands for posting positive endorsements (Schmitt, Skiera, and Van den Bulte 2011).

In terms of online WOM, SNS are very different to other eWOM conduit sites as their primary purpose is not commercial (Chu and Kim 2011). Instead SNS facilitate social exchanges among groups of known friends. Most major SNS platforms, for instance, Facebook, Google + , and LinkedIn, insist on the adoption of a Real User Policy, which removes user anonymity by disclosing users' real identities. Furthermore, SNS encourage users to connect online with their offline friends thus strengthening the tie strength relations between SNS-based connections (Chatterjee 2011). These characteristics of SNS enable a reintroduction of source credibility cues previously only considered inherent in offline WOM.

In addition to the discussion of the influence of tie strength relationships, there is a need to include the level of susceptibility the receiver exhibits toward interpersonal influence $^{1}$ and the weight they place on the recommendations of their peers. According to Bearden, Netemeyer, and Teel $(1989,473)$ : 'An important determinant of an individual's behaviour is others' influence'. Lee and Ma (2012), in their study of consumer perceptions of online reviews, find that the more susceptible the consumer is to interpersonal influence, the more they deem online eWOM as a useful source of consumer information. This confirms similar findings by both Park and Lee (2009) and Chu and Kim (2011), which show that the susceptibility characteristic of receivers impacts upon the likelihood of their being influenced by others.

Coupled with receivers' susceptibility to interpersonal influence is the related concept of susceptibility to trust, i.e. one's disposition to trust (McKnight and Chervany 2001). This characteristic is concerned with the extent to which a consumer 'is willing to depend on others' (McKnight and Chervany 2001, 45). Many consumers are willing to consistently place their faith in the trustfulness of other consumers. This enables them to accept (rather than dismiss) the eWOM recommendations they encounter online (Cheung et al. 2009).

Together, tie strength relationships and receivers' susceptibility to both trust in and be influenced by others are at the core of the community component of this eWOM credibility framework. SNS facilitate the community component by enabling friendship links and information transfer between known users. Consequently, as noted by Glaeser et al. (2000, 811): 'When individuals are closer socially, both trust and trustworthiness rise'.

\section{Competence}

The credibility component of competence is denoted by the relative expertise levels of both the sender and the receiver pertaining to the brand, the product, or the service at the 
centre of the WOM communication. Previous research places source expertise as a primary contributor to WOM credibility (Granovetter 1973; Anderson 1998; Phelps et al. 2004). In general, the greater experience consumers are known to have with a brand, the more believable their claims or recommendations, whether positive or negative. Consumer expertise may be attributed at either category or market level, identifying the WOM source as an opinion leader or market maven, respectively (Corey 1971; Feick and Price 1987). Source expertise is obtained not only through direct brand experience but also through greater consumption of media relating to developments in the marketplace in order to project one's in-depth knowledge of brands and the latest commercial innovations (Brooks 1957). eWOM enables novice customers to retrieve relevant information from experienced and credible others outside of their own interpersonal networks, which would have been otherwise impossible (Godes and Mayzlin 2009).

In addition to source expertise, the relative expertise of the eWOM receiver must also be considered (Gilly et al. 1998; Sweeney, Soutar, and Mazzarol 2008). It was previously accepted that as consumers gained more experience with products/services their reliance on WOM waned (Herr, Kardes, and Kim 1991); however, higher consumer expertise may make certain eWOM messages more accessible. This can be attributed to the level of involvement the recipient requires to accurately decipher the eWOM message. Involvement is considered an important factor in both the Elaboration Likelihood Model (ELM; Petty, Cacioppo, and Schumann 1983) and the Heuristic-Systematic Model (Chaiken 1980). In both models the higher the recipient's involvement with a product or service (i.e. the more weight and importance one places on the purchase decision) the more elaborate the mental processing of the message arguments that will occur. If involvement is low, recipients rely less on the content of the message, opting instead to rely on more accessible or intuitive/heuristic cues such as source characteristics as a proxy for credibility, resulting in adoption/non-adoption.

This consideration of involvement may also be extended to the product/service type. In general, services are considered much more difficult to evaluate before trial owing to their unique characteristics of intangibility and variability (Sweeney, Soutar, and Mazzarol 2014). This may result in more elaboration on the argument quality of services eWOM as consumers are more highly involved in reducing purchase dissonance (Ryu and Feick 2007). In a similar vein, Park and Lee (2009) also apply this distinction to experience goods over search goods in which they found eWOM to be more impactful when evaluation is based on trial.

Competence as a component of eWOM credibility therefore extends not only from the prior expertise levels of both members of the dyad, but also from the product/service characteristics and the level of processing involvement required by recipients. eWOM shared with individuals or groups of 'friends' on SNS can help non- 'fans' to learn from more experienced peers. SNS also allow consumers to connect their profiles with their preferred brands in order to project their experience with that brand and to benefit from affiliation with the brand's desirable identity (Wallace, Buil, and de Chernatony 2012). This heightened brand involvement may strengthen competence cues of credibility to eWOM recipients.

\section{Content}

The content of the eWOM message is another determinant of WOM credibility, manifested in the clarity and valence of the communication. The clarity of the message is dependent on both attribute ambiguity and language abstraction. Attribute ambiguity 
refers to the reasons put forth by consumers as to why they loved or hated the branded experience (Gershoff, Mukherjee, and Mukhopadhyay 2007). If the attributes resonate with the eWOM receiver and are deemed credible reasons for avoiding or purchasing a particular brand then the eWOM message is considered believable. The level of language abstraction used by customers when describing a branded experience may be either concrete or abstract, where concrete terms are representative of a recent experience and abstract language is associated with the customer's lifetime experience (Schellekens, Verlegh, and Smidts 2010). Message language and attributes are important as the receiver of the eWOM must be able to decode and comprehend the message in the same manner intended by the sender (Christiansen and Tax 2000).

Although message clarity is important, eWOM content is most often associated with the valence or sidedness of the message, which may be positive or negative. Positive and negative eWOM messages are associated with high levels of either customer satisfaction or dissatisfaction (Anderson 1998), and are likely shared to achieve balance though homeostase utility (Hennig-Thurau et al. 2004). eWOM can also provide a balanced overview of a consumption experience in which the reviewer offers both pros and cons for the recipient's consideration (Kamins and Assael 1987). Of these valences, negative eWOM is often deemed the most diagnostic as it is least ambiguous (Anderson 1998). It is easier for consumers to categorise goods as being of low quality based on negative WOM compared with positive WOM categorisation as most goods have some positive attributes (Herr, Kardes, and Kim 1991). In contrast, rather than there being a prevalent negativity effect, Gershoff, Mukherjee, and Mukhopadhyay (2007) show that there is a higher likelihood of a positivity effect of eWOM owing to the multitude of messages available. This adds support to Kimmel and Kitchen (2014) whose review of positive versus negative WOM failed to conclude in the favour of a greater impact of negative WOM. Yet Reichelt, Sievert, and Jacob $(2014,65)$ warn that 'eWOM readers might doubt the credibility of information if it is mostly positive'.

Brand-related messages of all three above valences are found on SNS. In addition, neutral eWOM also occurs (Cheung and Thadani 2010). Neutral eWOM does not offer either a positive or negative stance; rather it is most likely shared for informational purposes such as highlighting a branded update which 'friends' may find interesting. Consumers are adept at using Web 2.0 technologies to produce and disseminate eWOM content to express themselves and their brand preferences (Christodoulides 2009).

Attribution theory (Kelley 1973) is a useful guide to understanding the content component of credibility. Attribution theory suggests that the more a product review can be attributed to stimulus level characteristics (i.e. product quality or functionality), the more credible the WOM will be deemed by receivers. However, if the WOM message is perceived to be based on non-stimulus attributes such as incentives or personal satisfaction then the Discounting Principle of Attribution Theory is used (Kelley 1973; Lee and Youn 2009). This discounting dampens the sincerity of the communication, diminishing credibility.

\section{Consensus}

WOM messages are more believable if they comply with the receiver's own judgements and concur with other available WOM messages about the brand (Gatignon and Robertson 1986; Leonard-Barton 1985). WOM messages which reinforce consumer preconceptions of branded experiences satisfy consumer curiosity and strengthen feelings of expertise (Anderson 1998). This is related to the personal relevance component of the ELM in which 
receivers pay more attention to and are motivated to elaborate further on information which holds personal relevance and consequences for them (Petty, Cacioppo, and Schumann 1983). A joint interest linking a source and a receiver is likely to result in greater interaction between the pair, resulting in more impactful and credible eWOM communications (van Noort, Antheunis, and van Reijmersdal 2012).

Review consistency is also important as the consensus of eWOM information enables customers to reduce their purchase dissonance and mitigate the risks of making a 'bad' purchase decision (Ryu and Feick 2007). Review consistency can be an important 'heuristic' cue of credibility (Cheung, Sia, and Kuan 2012), which many third party eWOM hosting websites try to leverage by displaying aggregated review information to users (Dellarocas 2003). However, there may be temporal concerns with consensus of information as over time consumers may supplement the eWOM they receive with their own brand experiences (Christiansen and Tax 2000). For the most part though, new eWOM messages will be judged in accordance with their agreement with the eWOM messages which have preceded them. If the majority of eWOM information portrays a brand in a similar light, it is more credible than opposing eWOM (Gershoff, Mukherjee, and Mukhopadhyay 2007). Agreement among consumers increases the believability of the message, as noted by Amblee and Bui $(2012,91)$ : 'Consumers rely on collaboratively shared information and experiences of others to infer a course of action'.

Consensus of eWOM information on SNS can be attributed to the number of 'likes' and 'clicks' a post receives. However, there are concerns regarding the growing trend of brand-initiated eWOM on SNS, which compensates customers in exchange for spreading positive, firm-generated eWOM communications with their friend connections. This brand-induced eWOM may jar with the receivers' own judgement based on their previous branded experiences which could detract from the credibility of the eWOM message, negatively impacting upon the relationship between the receiver and the eWOM source (Abendroth and Heyman 2013).

\section{Managerial and theoretical implications}

It is often believed that credibility is inherent in WOM practices as consumers trust the opinions and experiences of their peers far more than they trust marketers (Lee and Youn 2009; Kozinets et al. 2010). However, the notion of inherent credibility runs the risk of being taken for granted as marketers engage in WOM manipulation through controlled WOM marketing campaigns and provision of customer rewards. This highlights a greater need for academic and practitioner understanding of what constitutes credibility within online WOM communications in order to preserve its integrity.

This paper has attempted to clarify where credibility lies within eWOM activities by examining the credibility attached to both the source and the message. Source and message credibility each comprise two distinct components, which when taken together produce the 4Cs of Credibility: community, competence, content, and consensus. Uncovering the means by which credibility is determined within each of these contributory factors, a clearer understanding of how consumers decipher eWOM communications and judge their credibility is proposed.

A greater understanding of eWOM credibility adds to the growing body of digital marketing and eWOM literature. This framework is the first to attempt a synthesis of the multitude of factors which affect both source and message credibility in the online, social networking environment. Drawing on previous theory and models, the eight credibility factors outlined are explicitly related to eWOM shared among SNS-based 'friends'. 
Although the credibility of eWOM is generally perceived as more ambiguous than traditional WOM (Benedicktus and Andrews 2006), SNS cross the divide and enable many of the traditional signals of credibility determination to be applied in the online environment. This is due to SNS replicating a consumer's offline interpersonal network in the digital world (Chatterjee 2011), while also allowing users to express their likes and interests through personalised profile pages (Trusov, Bucklin, and Pauwels 2009). Thus, the framework has implications for brand managers who aim to engage with communities of 'friends' through SNS. For managers, the most important consideration for harnessing and leveraging eWOM should be the maintenance of credibility. By ensuring credibility, marketers stand a better chance of leveraging peer-to-peer communications for commercial gain.

Focusing on the four components of community, competence, content, and consensus should drive better firm-generated communications, replicating the tone and enthusiasm of satisfied customers. The 'hard sell' and 'corporate speak' are not ingredients of viral marketing and serve no purpose in SNS. Instead a focus on community conversation, underpinned by credible communications should enable managers to drive user engagement. Furthermore, the credibility framework can be used by firms and market researchers to identify the most suitable eWOM to leverage for promotional purposes such as to pin to the top of a brand's SNS page or to serve as customer endorsements on the brands' websites.

The credibility framework also offers some theoretical implications and encourages future research in this highly evolving area. This is the first paper to attempt to collate various credibility components into one framework. Furthermore, it is also the first to specifically consider the credibility determination of eWOM in SNS. As more brands interact with 'fans'/customers online, these interactions are visible to the users' online network of 'friends'. The credibility of subsequent firm-generated or leveraged eWOM activities may be positively affected because of the known user-brand connection. This usefully extends the framework as a means to deepen engagement with 'fans' in order to recruit their 'friend' connections.

The 4Cs framework, while conceptual in nature, adopts components from previously verified and validated credibility models. Yet empirical validation of this framework is a necessary next step to better outline eWOM credibility in the online environment. In addition, looking at the interactions between components would be useful to determine under which conditions is eWOM credibility enhanced or diminished. For instance, as tiestrength relationships in SNS are considered strong owing to the replication of offline friendships, do users place more demands upon senders' expertise if they specifically affiliate themselves with an SNS-based brand page? Or is the credibility of a message which lacks clarity more easily understood and deciphered due to prior experience communicating with the source through SNS? Furthermore, should incentives be used by marketers to encourage the spread of brand-initiated eWOM, how does the presence of the reward affect user perceptions of eWOM credibility? Overall, credibility is very important to the acceptance and adoption of eWOM on SNS; marketers must not take it for granted in the pursuit of short-term gains.

\section{Conclusion}

Brands strive for consumer engagement on SNS in the hope of leveraging the friend connections of their followers. Firm-controlled eWOM campaigns offer brands the ability to spread positive messages for the purposes of building awareness and acquiring new 
customers. However, the proliferation of incentivised eWOM campaigns poses threats to the credibility of the communication as the eWOM lacks sincerity. Further, the sender may appear to be solely chasing economic gain. True eWOM consists of consumers sharing their own experiences of brand consumption with their peers. The inherent credibility of WOM extends from this personalised communication, which is unsullied by marketer agenda.

EWOM credibility therefore can be quite fragile; thus, it requires genuine management to protect its integrity. The 4Cs of Credibility Framework may be used by practitioners to craft credible eWOM campaigns which replicate $\mathrm{C} 2 \mathrm{C}$ communications and resonate with brands' online fans. Further, it can help academics and marketing researchers to better analyse existing brand-related eWOM to decipher its credibility and determine its capability for leverage across online social networks. Through a deeper understanding of eWOM credibility, brands will be able to propagate credible endorsements on SNS to attract new fans.

\section{Note}

1. The authors would like to thank an anonymous reviewer for this suggestion.

\section{Notes on contributors}

Gillian Moran is a PhD candidate at the UCD Michael Smurfit Graduate School of Business and the recipient of the inaugural Anthony C. Cunningham Doctoral Scholarship in Marketing. Her research interests include e-word of mouth, social media marketing and digital branding, specifically on how these activities are impacting upon and changing consumer behaviour. Her work has recently appeared in the Journal of Advertising Research.

Laurent Muzellec is the Programme Director of the M.Sc. in Digital Marketing at UCD Michael Smurfit Graduate Business School. He advises senior marketing executives on digital opportunities and social media strategies. His academic work has appeared in several international publications including Industrial Marketing Management, Marketing Theory, the Journal of Product and Brand Management and the European Journal of Marketing.

\section{References}

Abendroth, L. J., and J. E. Heyman. 2013. "Honesty Is the Best Policy: The Effects of Disclosure in Word-of-Mouth Marketing." Journal of Marketing Communications 19 (4): 245-257.

Amblee, N., and T. Bui. 2012. "Harnessing the Influence of Social Proof in Online Shopping: The Effect of Electronic Word of Mouth on Sales of Digital Microproducts." International Journal of Electronic Commerce 16 (2): 91-113.

Anderson, E. W. 1998. "Customer Satisfaction and Word of Mouth.” Journal of Service Research 1 (1): $5-17$.

Bearden, W. O., R. G. Netemeyer, and J. E. Teel. 1989. "Measurement of Consumer Susceptibility to Interpersonal Influence." Journal of Consumer Research 15: 473-481.

Benedicktus, R. L., and M. L. Andrews. 2006. "Building Trust with Consensus Information: The Effects of Valence and Sequence Direction." Journal of Interactive Advertising 6 (2): 17-29.

Brooks, R. 1957. “'Word-of-Mouth' Advertising in Selling New Products.” Journal of Marketing 22: $154-161$.

Brown, J. J., and P. Reingen. 1987. "Social Ties and Word-of-Mouth Referral Behavior." Journal of Consumer Research 14: 350-362.

Chaiken, S. 1980. "Heuristic versus Systematic Information Processing and the Use of Source versus Message Cues in Persuasion." Journal of Personality and Social Psychology 39 (5): 752-766.

Chatterjee, P. 2011. "Drivers of New Product Recommending and Referral Behaviour on Social Network Sites." International Journal of Advertising 30 (1): 77-101. 
Cheung, M. Y., C. Luo, C. L. Sia, and H. Chen. 2009. "Credibility of Electronic Word-of-Mouth: Informational and Normative Determinants of On-line Consumer Recommendations." International Journal of Electronic Commerce 13 (4): 9-38.

Cheung, M. Y., C. L. Sia, and K. K. Y. Kuan. 2012. "Is this Review Believable? A Study of Factors Affecting the Credibility of Online Consumer Reviews from an ELM Perspective." Journal of the Association for Information Systems 13 (8): 618-635.

Cheung, C. M. K., and D. R. Thadani. 2010. "The Effectiveness of Electronic Word-of-Mouth Communication: A Literature Analysis.” 23rd BLED eConference 2010 Proceedings. Paper 18, 329-345. Accessed October 5, 2012. http://aisel.aisnet.org/bled2010/18

Christiansen, T., and S. S. Tax. 2000. "Measuring Word of Mouth: The Questions of Who and When?" Journal of Marketing Communications 6 (3): 185-199.

Christodoulides, G. 2009. "Branding in the Post-Internet Era." Marketing Theory 9 (1): 141-144.

Chu, S-C., and Y. Kim. 2011. "Determinants of Consumer Engagement in Electronic Word-ofMouth (eWOM) in Social Networking Sites." International Journal of Advertising 30 (1): $47-75$.

Corey, L. G. 1971. "People Who Claim to be Opinion Leaders: Identifying Their Characteristics by Self-report." Journal of Marketing 36: 48-63.

Dellarocas, C. 2003. "The Digitization of Word of Mouth: Promise and Challenges of Online Feedback Mechanisms." Management Science 49 (10): 1407-1424.

Dichter, E. 1966. "How Word-of-Mouth Advertising Works." Harvard Business Review 16: $147-166$.

Duhan, D. F., S. D. Johnson, J. B. Wilcox, and G. D. Harrell. 1997. "Influences on Consumer Use of Word of Mouth Recommendation Sources." Journal of the Academy of Marketing Science 25 (4): 283-295.

Feick, L. F., and L. L. Price. 1987. "The Market Maven: A Diffuser of Marketplace Information.” Journal of Marketing 51: 83-97.

Fong, J., and S. Burton. 2006. "Electronic Word-of-Mouth: A Comparison of Stated and Revealed Behavior on Electronic Discussion Boards." Journal of Interactive Advertising 6 (2): 61-70.

Gatignon, H., and T. S. Robertson. 1986. "An Exchange Theory Model of Interpersonal Communication." Advances in Consumer Research 13 (1): 534-538.

Gershoff, A. D., A. Mukherjee, and A. Mukhopadhyay. 2007. "Few Ways to Love, but Many Ways to Hate: Attribute Ambiguity and the Positivity Effect in Agent Evaluation." Journal of Consumer Research 33: 499-505.

Gilly, M. C., J. L. Graham, M. F. Wolfinbarger, and L. J. Yale. 1998. "A Dyadic Study of Interpersonal Information Search." Journal of the Academy of Marketing Science 26 (2): $83-100$.

Glaeser, E. L., D. I. Laibson, J. A. Scheinkman, and C. L. Soutter. 2000. "Measuring Trust." The Quarterly Journal of Economics 115 (3): 811-846.

Godes, D., and D. Mayzlin. 2009. "Firm-Created Word-of-Mouth Communication: Evidence from a Field Test." Marketing Science 28 (4): 721-739.

Granovetter, M. S. 1973. “The Strength of Weak Ties." American Journal of Sociology 78: $1360-1380$.

Gruen, T. W., T. Osmonbekov, and A. J. Czaplewski. 2005. "How E-communities Extend the Concept of Exchange in Marketing: An Application of the Motivation, Opportunity, Ability (MOA) Theory." Marketing Theory 5 (1): 33-49.

Hennig-Thurau, T., K. P. Gwinner, G. Walsh, and D. D. Gremler. 2004. "Electronic Word-of-Mouth via Consumer-Opinion Platforms: What Motivates Consumers to Articulate Themselves on the Internet?" Journal of InteractiveMarketing 18 (1): 38-52.

Herr, P. M., F. R. Kardes, and J. Kim. 1991. "Effects of Word-of-Mouth and Product-Attribute Information on Persuasion: An Accessibility-Diagnosticity Perspective." Journal of Consumer Research 17: 454-465.

Hollebeek, L. D. 2011. "Demystifying Customer Brand Engagement: Exploring the Loyalty Nexus." Journal of Marketing Management 27 (7-8): 785-807.

Hovland, C. I., and W. Weiss. 1951. "The Influence of Source Credibility on Communication Effectiveness." Public Opinion Quarterly 15 (4): 635-650.

Kamins, M. A., and H. Assael. 1987. "Two-sided Versus One-sided Appeals: A Cognitive Perspective on Argumentation, Source Derogation, and the Effect of Disconfirming Trial on Belief Change." Journal of Marketing Research 24 (1): 29-39. 
Kelley, H. H. 1973. "The Processes of Causal Attribution.” American Psychologist 28 (2): 107-128.

Kimmel, A. J., and P. J. Kitchen. 2014. "WOM and Social Media: Presaging Future Directions for Research and Practice." Journal of Marketing Communications 20 (1/2): 5-20.

Kozinets, R. V., K. de Valck, A. C. Wojnicki, and S. J. S. Wilner. 2010. "Networked Narratives: Understanding Word-of-Mouth Marketing in Online Communities." Journal of Marketing 74: $71-89$.

LaPointe, P. 2012. "Measuring Facebook's Impact on Marketing: The Proverbial Hits the Fan." Journal of Advertising Research 52 (3): 286-287.

Lee, H-H., and Y. J. Ma. 2012. "Consumer Perceptions of Online Consumer Product and Service Reviews. Focusing on Information Processing Confidence and Susceptibility to Peer Influence." Journal of Research in Interactive Marketing 6 (2): 110-132.

Lee, M., and S. Youn. 2009. "Electronic Word of Mouth (eWOM): How eWOM Platforms Influence Consumer Product Judgement." International Journal of Advertising 28 (3): 473-499.

Leonard-Barton, D. 1985. "Experts as Negative Opinion Leaders in the Diffusion of a Technological Innovation." Journal of Consumer Research 11: 914-926.

Liu, Y. 2006. "Word of Mouth for Movies: Its Dynamics and Impact on Box Office Revenue." Journal of Marketing 70: 74-89.

McKnight, D. H., and N. L. Chervany. 2001. "What Trust Means in E-Commerce Customer Relationships: An Interdisciplinary Conceptual Typology." International Journal of Electronic Commerce 6 (2): 35-59.

Moran, G., L. Muzellec, and E. Nolan. 2014. "Consumer Moments of Truth in the Digital Context." Journal of Advertising Research 54 (2): 200-204.

Nelson-Field, K., E. Riebe, and B. Sharp. 2012. "What's Not to 'Like?' Can a Facebook Fan Base Give a Brand The Advertising Reach It Needs?" Journal of Advertising Research 52 (2): $262-269$.

Palmer, A., and Q. Huo. 2013. "A Study of Trust Over Time Within a Social Network Mediated Environment." Journal of Marketing Management 29 (15-16): 1816-1833.

Park, C., and T. M. Lee. 2009. "Information Direction, Website Reputation and eWOM Effect: A Moderating Role of Product Type." Journal of Business Research 62 (1): 61-67.

Park, D-H., J. Lee, and I. Han. 2007. "The Effect of On-Line Consumer Reviews on Consumer Purchasing Intention: The Moderating Role of Involvement." International Journal of Electronic Commerce 11 (4): 125-148.

Petty, R., J. T. Cacioppo, and D. Schumann. 1983. "Central and Peripheral Routes to Advertising Effectiveness: The Moderating Role of Involvement." Journal of Consumer Research 10 (3): $135-146$

Phelps, J. E., R. Lewis, L. Mobilio, D. Perry, and N. Raman. 2004. "Viral Marketing or electronic Word-of-Mouth Advertising: Examining Consumer Responses and Motivations to Pass Along Email." Journal of Advertising Research 44 (4): 333-348.

Reichelt, J., J. Sievert, and F. Jacob. 2014. "How Credibility Affects eWOM Reading: The Influences of Expertise, Trustworthiness, and Similarity on Utilitarian and Social Functions." Journal of Marketing Communications 20 (1-2): 65-81.

Ryu, G., and L. Feick. 2007. "A Penny for Your Thoughts: Referral Reward Programs and Referral Likelihood." Journal of Marketing 71: 84-94.

Schellekens, G., P. Verlegh, and A. Smidts. 2010. "Language Abstraction in Word of Mouth." Journal of Consumer Research 37: 207-223.

Schmitt, P., B. Skiera, and C. Van den Bulte. 2011. "Referral Programs and Customer Value." Journal of Marketing 75: 46-59.

Sweeney, J. C., G. N. Soutar, and T. Mazzarol. 2008. "Factors Influencing Word of Mouth Effectiveness: Receiver Perspectives." European Journal of Marketing 42 (3): 344-364.

Sweeney, J. C., G. N. Soutar, and T. Mazzarol. 2014. "Factors Enhancing Word-of-Mouth Influence: Positive and Negative Service-Related Messages." European Journal of Marketing 48 (1/2): $336-359$.

Trusov, M., R. E. Bucklin, and K. Pauwels. 2009. "Effects of Word-of-Mouth versus Traditional Marketing: Findings from an Internet Social Networking Site." Journal of Marketing 73: 90-102.

van Noort, G., M. L. Antheunis, and E. A. van Reijmersdal. 2012. "Social Connections and the Persuasiveness of Viral Campaigns in Social Network Sites: Persuasive Intent as the Underlying Mechanism." Journal of Marketing Communications 18 (1): 39-53. 
Wallace, E., I. Buil, and L. de Chernatony. 2012. "Facebook 'Friendship' and Brand Advocacy." Journal of Brand Management 20 (2): 128-146.

Wirtz, J., and P. Chew. 2002. "The Effects of Incentives, Deal Proneness, Satisfaction and Tie Strength on Word-of-Mouth Behaviour." International Journal of Service Industry Management 13 (2): $141-162$. 